\title{
Selection of structural system for wooden public building: Multiple criteria approach
}

\author{
Laura Tupenaite ${ }^{1}$, Tomas Gecys ${ }^{2,6}$, Loreta Kanapeckiene ${ }^{3}$, \\ Seyed Masoud Sajjadian ${ }^{4}$, Jurga Naimaviciene ${ }^{5}$ \\ 1,3,5 Department of Construction Management and Real Estate, Faculty of Civil Engineering, \\ Vilnius Gediminas Technical University, Vilnius, Lithuania \\ ${ }^{2}$ Department of Steel and Composite Structures, Faculty of Civil Engineering, \\ Vilnius Gediminas Technical University, Vilnius, Lithuania \\ ${ }^{4}$ Southampton Solent University, Southampton, United Kingdom \\ ${ }^{6}$ JSC "Idea Statika", Vilnius, Lithuania \\ E-mail: 'laura.tupenaite@vgtu.lt (correspondingauthor)
}

\begin{abstract}
There has been a growing interest in the construction industry for using materials with lower environmental impacts, in this context, stakeholders increasingly seeing wood as the natural and sustainable option for public buildings. Studies worldwide have already investigated modern structural systems for wooden construction. However, the selection of alternative structural systems is rarely discussed, alternatives are seldom compared. To close a gap this paper proposes a framework for selection of the structural system for a wooden public building based on a Simple Additive Weighting (SAW) multiple criteria assessment method. The proposed methodology is applied for the case of a public wooden building - shopping centre in Lithuania. Three structural systems (1) double tapered glued laminated beams and columns, (2) laminated veneer lumber (LVL) trusses and columns and (3) single tapered glued laminated beam and I type steel column are compared. The research allowed distinguishing the most efficient structural system according to eight conflicting quantitative and qualitative criteria, which, in this case, contains double tapered glued laminated beams and columns. Proposed assessment framework is relatively simple to apply, therefore can be successfully used in practice.
\end{abstract}

Keywords: wooden construction, structural systems, public building, multiple criteria assessment.

\section{Introduction}

It seems that wood has become a more popular choice in construction worldwide. Through engineered products solid wood components can be manufactured to span distances of 40 metres. The low weight simplifies transport and installation, which also has a positive financial advantage. Timber is also an efficient material in structures, or their parts, in which a high proportion of the load to be resisted is the self-weight of the structure itself (Ramage et al., 2017). Therefore, a significant number of constructed buildings are built in wood-framed technology (Malesza, Miedzialowski, \& Ustinovichius, 2019).

Timber has substantial environmental benefits. Trees absorb $\mathrm{CO}_{2}$ from the atmosphere, store the carbon and release $\mathrm{O}_{2}$. Timber, used in construction, continues to store carbon. The processing and transportation of timber requires less energy than steel and concrete. Wood is a good insulator; therefore less energy is required for heating and cooling of wooden buildings. Finally, number of studies shown that timber elements have less global warming emissions than steel or concrete (Harte, 2009).

Wood's millennial history as a building material makes it one of the oldest building materials. In comparison, steel has only been used for buildings since the 1880 s and modern concrete since the $1850 \mathrm{~s}$. It may, therefore, seem paradoxical that wood is not selected as a major material for public buildings. The explanation is that the large industrial-processed solid wooden elements that have made it technically possible to build large wooden buildings are relatively a new invention. The lack of focus on wood in European countries can also be explained not only by the lack of tradition but also other factors such as the regulatory frameworks, lack of recognition and understanding of environmental benefits, uncertain economic sustainability and technical know-how. According to Hildebrandt, Hagemann, and Thrän (2017), engineered timber products have already been substituted for carbon and energy-intensive concrete and steel-based building constructions, but they still lack the capacities and market demand. 
Different studies worldwide investigate modern structural systems for wooden construction. However, selection of alternative structural systems is a multi-faceted problem which is rarely discussed, alternatives are seldom compared, and research is very limited. To close a gap this paper aims to propose the framework for selection of the efficient structural system based on a multiple criteria assessment method.

The paper contains literature review on multiple criteria decision-making (MCDM) applications in the field of construction engineering, proposes a methodology for selection of the structural system based on SAW multiple criteria assessment method, demonstrates a practical application of the proposed methodology: a public wooden building project is selected, alternative structural systems described and criteria for comparison and their significances determined, multiple criteria assessment to find the most efficient solution by SAW method performed. The last section concludes the paper, provides limitations and insights for future research.

\section{Literature review}

Multiple criteria decision-making techniques can assist engineers in making the best choice of different alternatives according to criteria from many sources which may conflict with each other. MCDM techniques have been one of the fast-growing areas in construction engineering during the past two decades (Balali, Mottaghi, Shoghli, \& Golabchi, 2014). The review by Zavadskas, Antucheviciene, Vilutiene, and Adli (2018) revealed that MCDM applications have particularly increased in the last three years, confirming the great potential and prospects for sustainable decision-making in civil engineering, construction and building technology.

Balali, Zahraie, Hosseini, and Roozbahani (2010) applied the PROMETHEE (Preference Ranking Organization Method for Enrichment Evaluation) multicriteria decision making technique for selection of the most appropriate structural system for multi-housing projects. More recently, Balali et al. (2014) applied the same method for the selection of material, construction technique, and structural system for the Kashkhan Bridge in Iran. Frenette, Derome, Beauregard, and Salenikovich (2008) used a multi-criteria framework to evaluate factory-built wood-frame exterior walls.

Turskis, Urbonas, and Daniūnas (2019) investigated and compared five possible symmetrical structural solutions for buildings. They have applied the Analytic Hierarchy Process (AHP) method to determine weights of criteria, the fuzzy Additive Ratio Assessment (ARAS-F), and the fuzzy product model (MULT-F) for multi-criteria assessment of feasible alternatives. Šaparauskas, Zavadskas, and Turskis (2010) selected the most suitable facade system to cover a building by MCDM techniques. Tamošaitiené and Gaudutis (2013) applied COmplex PRoportional ASsessment of Alternatives with Grey Relations (COPRAS-G) method for selection of a structural system for a high-rise building. COPRAS, Mixed Data (EVAMIX), and SAW methods were also used for materials' selection (Chatterjee, Athawale, \& Chakraborty, 2011; Lill, Kanapeckiene, Tupenaite, \& Naimaviciene, 2017). Evaluation of the construction methods of cold-formed steel structures in reconstructing the areas damaged in natural crises using the AHP and COPRAS-G methods was performed by Bitarafan, Hashemkhani Zolfani, Arefi, and Zavadskas (2012). Haghnazar Kouchaksaraei, Hashemkhani Zolfani, and Golabchi (2015) proposed glasshouse locating based on Step-Wise Weight Assessment Ratio Analysis (SWARA) and COPRAS approaches. Šiožinytė, Antuchevičienė, and Kutut (2014) used TOPSIS Grey (Technique for Order Preference by Similarity to Ideal Solution with grey numbers) and AHP methods to select rational vernacular building's modernisation variant. Turskis, Morkunaite, and Kutut (2017) integrated two MCDM methods - AHP and Evaluation Based on Distance from Average Solution (EDAS) to evaluate the cultural heritage structures.

Literature analysis reveals that MCDM techniques are extensively applied in the field of construction engineering, however, multiple criteria evaluation of alternative wooden structural systems is rarely performed. To close a gap this paper proposes an approach for selection of the structural system for a public building based on MCDM technique.

\section{Methodology}

Literature review revealed various MCDM methods that can be used for selection of structural systems. Authors of this paper aimed to provide simple and clearly understandable assessment approach; therefore SAW (Simple Additive Weighting) method was selected. SAW method was summarized by MacCrimmon (1968). It is also described as the oldest, most widely known and practically used method (Podvezko, 2011).

A proposed framework for selection of the most rational structural system in the case of construction of a wooden public building is illustrated in Figure 1. Multiple criteria evaluation according to SAW method contains several steps:

1. Analysis of customer requirements for public wooden building.

2. Design of alternative structural systems according to customer requirements.

3. Multiple criteria assessment of alternative structural systems:

a) Development of the decision-making matrix according to Eq. (1) (Figure 1), where $n$ - number of alternatives; $m$ - number of attributes; $x_{i j}$ - the attribute value of the $j$ th alternative; 
b) Determining the optimal values of each parameter according to Eq. (2) (Figure 1);

c) Normalization of decision-making matrix according to Eq. (3) (Figure 1);

d) Determining criteria weights $q_{i}$ by survey of experts or consulting with customer;

e) Calculation of weighted normalized matrix by multiplying values of matrix by corresponding significances of each criterion according to Eq. (4) (Figure 1);

f) Determining efficiency of each $j^{\text {th }}$ alternative according to Eq. (5) (Figure 1);

g) Ranking of alternatives.

4. Selection of the most rational structural system alternative.

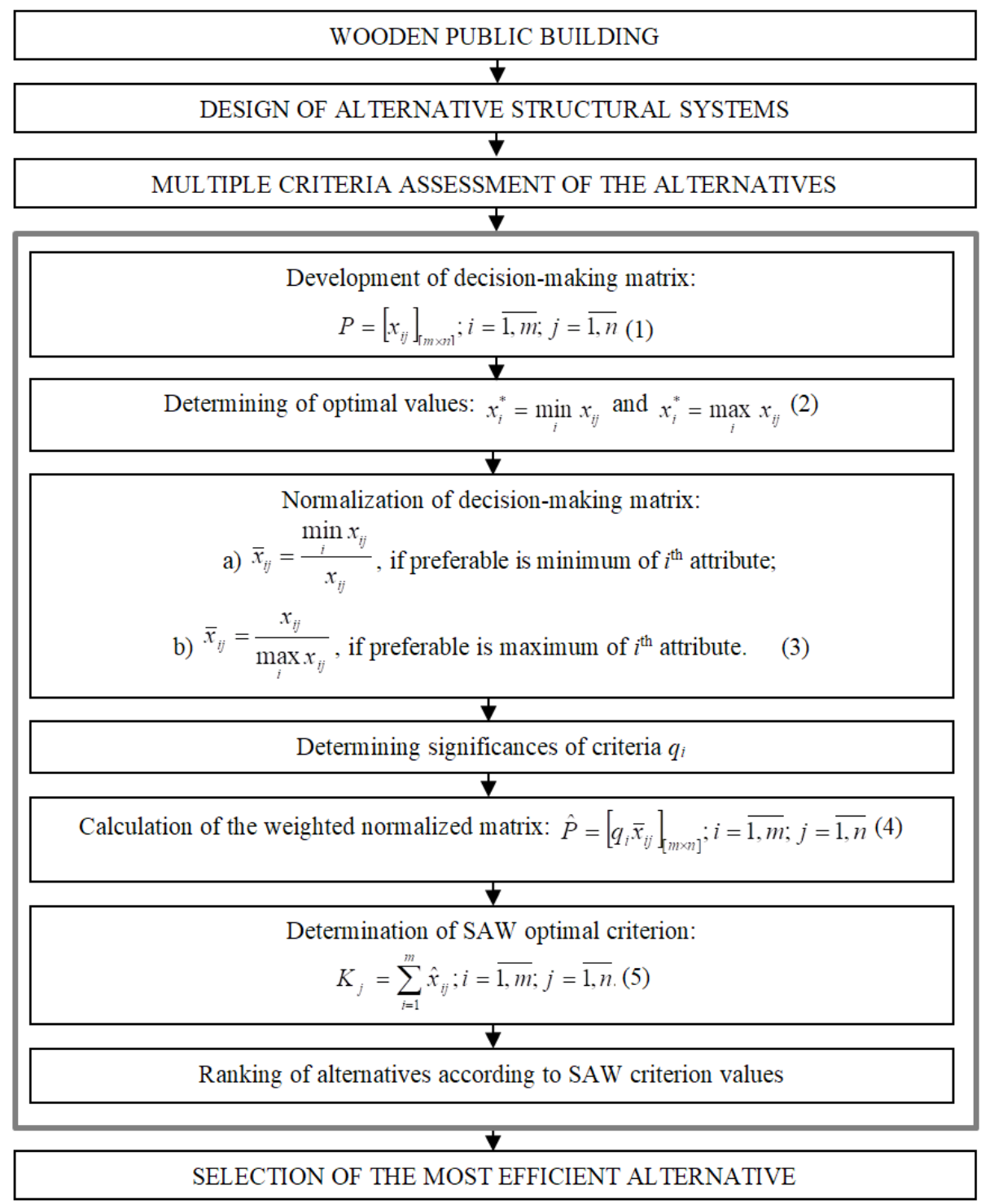

Figure 1. Framework for selection of the structural systems for wooden public building (source: developed by authors)

\section{Case study}

\section{Description of the project}

This section presents the application of the multi-criteria assessment method for selection of structural systems for one of the most typical shopping centres in Lithuania. Nowadays in Lithuania these shopping centres are being built using the reinforced concrete columns and glued laminated beams. Dimensions in the layout of the typical centre are $40 \times 50 \mathrm{~m}$, it is around $2000 \mathrm{~m}^{2}$ in total. The dimensions in the layout may vary taking into account the configuration of site plan. The purposed distance between central axes of columns is $5.0 \mathrm{~m}$ in the longitudinal direction of the building and $20 \mathrm{~m}$ in transverse direction. The columns are arranged across the perimeter of the building every 5 meters. The maximum altitude of ridge line is 6.0 meters from floor level, so the height of the roof load bearing structure has significant influence on the internal volume of building. The roof structure is installed with a 3 percent 
incline for water removal. After evaluation of architectural and functional requirements of the building, three alternative structural solutions using timber-based products are purposed, which are further discussed.

\section{Alternative structural systems}

The first alternative structural system $A_{1}$ is composed of glued laminated timber, glued laminated columns and double tapered beams, as shown in Figure 2. Glued laminated columns are fixed rigidly to the foundations while glued laminated beams are flexibly supported on columns. Double tapered glued laminated beams form a slope which is necessary for water removal from roof. Glued laminated timber strength classes may be GL24, GL28, GL32, and GL36 according to standard EN 14080 (CEN, 2013). The straight axis elements may be glued up to $240 \mathrm{~mm}$ width, $2200 \mathrm{~mm}$ height and a maximum length may reach 40 meters.

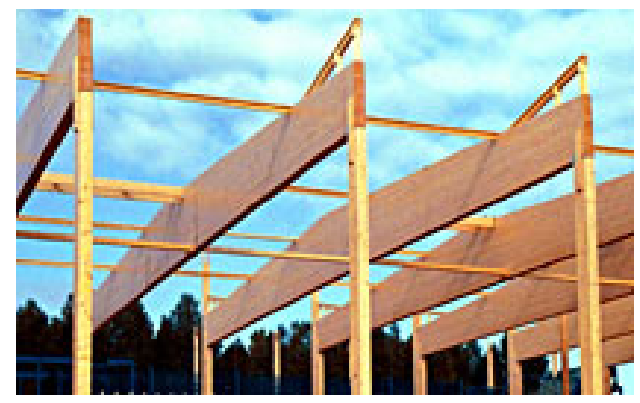

Figure 2. Alternative $A_{1}$ - double tapered glued laminated beams and columns (source: GLTA, 2019)

The second alternative structural system $A_{2}$ is made of laminated veneer lumber LVL (according to standard EN 14374 (CEN, 2004)) columns and double tapered trusses, as shown in Figure 3. LVL is an engineered wood product that uses multiple layers of thin wood assembled with adhesives. In the latter structural system columns are rigidly fixed to the foundation and trusses are flexibly supported on columns. LVL is chosen for truss elements after an evaluation that standard beams may be glued up to $600 \mathrm{~mm}$ in height and $300 \mathrm{~mm}$ in width with a maximum length of up to $18 \mathrm{~m}$. The transportation of the structure is easier if using LVL trusses, as $20 \mathrm{~m}$ length truss is divided into two separate parts up to $10 \mathrm{~m}$ which are assembled in one integral element on the construction site.

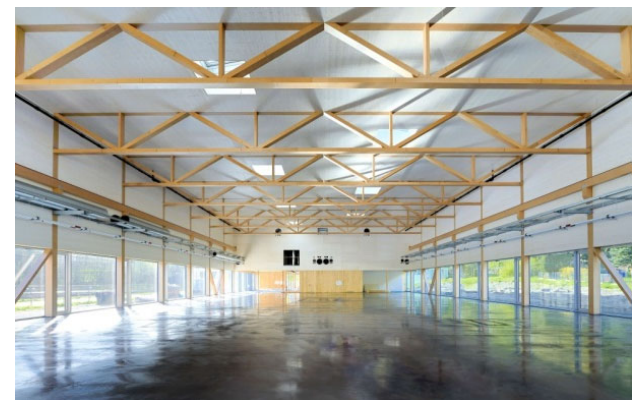

Figure 3. Alternative $A_{2}$ - laminated veneer lumber (LVL) trusses and columns (source: Pollmeier, 2019)

The third alternative structural system $A_{3}$ is hybrid which consists of I type standard steel beams and tapered glued laminated beams, as sown in Figure 4. This structural system is a typical three hinge hybrid frame in which beams and columns are rigidly connected while the connection between beams is pinned. Columns are also supported to the foundation flexibly which results to easier and cheaper foundations, as bending moments are not transferred to the foundation.

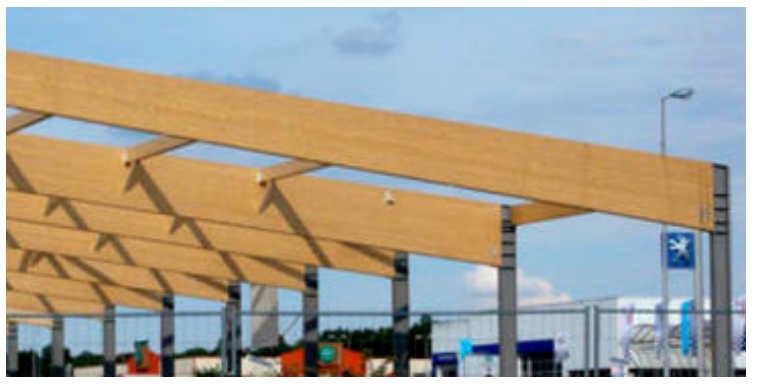

Figure 4. Alternative $A_{3}$ - single tapered glued laminated beam and I type steel column (source: Archi Expo, 2019) 


\section{Assessment criteria and their significances}

Three alternative structural systems are evaluated using a system of eight quantitative and qualitative criteria (Table 1). Criteria were selected by means of literature analysis and clarified according to practical experience of the authors. Significances of criteria were determined by the authors while consulting the project's customer.

Table 1. Description of the assessment criteria (source: developed by authors)

\begin{tabular}{|c|c|c|c|c|c|}
\hline & Criterion & $\begin{array}{l}\operatorname{Max} / \\
\text { Min* }\end{array}$ & $\begin{array}{c}\text { Measuring } \\
\text { unit }\end{array}$ & Description & Significance \\
\hline$q_{1}$ & $\begin{array}{l}\text { Achieved useful } \\
\text { height of the } \\
\text { building }\end{array}$ & Max & $\mathrm{m}$ & $\begin{array}{l}\text { Actual usable height depending on the activity that needs to be } \\
\text { carried out indoors. For a shopping center, it is important to } \\
\text { know this height to calculate the total volume of the building. } \\
\text { Higher usable height is preferred. }\end{array}$ & 0.08 \\
\hline$q_{2}$ & $\begin{array}{l}\text { Partial factor } \\
\text { for material }\end{array}$ & Min & coefficient & $\begin{array}{l}\text { Coefficient defines the scatter and reliability of the strength and } \\
\text { stiffness properties of the material. Coefficient close to } 1.0 \text { is } \\
\text { preferred. }\end{array}$ & 0.13 \\
\hline$q_{3}$ & $\begin{array}{l}\text { Eco-friendliness } \\
\text { of materials }\end{array}$ & Max & points & $\begin{array}{l}\text { Naturalness of the materials and their environmental perfor- } \\
\text { mance, determined by assessing environmental impact in the } \\
\text { processes of raw material extraction, production, use and dispos- } \\
\text { al. Qualitative indicator, assessed in 10-points scale by experts: } \\
1=\text { lowest eco-friendliness, } 10=\text { highest eco-friendliness. }\end{array}$ & 0.1 \\
\hline$q_{4}$ & $\begin{array}{l}\text { Massiveness of } \\
\text { structure }\end{array}$ & Min & points & $\begin{array}{l}\text { Determined in terms of maximum dimensions and mass of entire } \\
\text { and integral structural element. Compact elements are easier to } \\
\text { transport. Qualitative indicator, assessed in } 10 \text {-points scale by } \\
\text { experts: } 1=\text { highest compactness, } 10=\text { lowest compactness } \\
\text { (massive elements). }\end{array}$ & 0.1 \\
\hline$q_{5}$ & $\begin{array}{l}\text { Structural } \\
\text { aesthetics }\end{array}$ & Max & points & $\begin{array}{l}\text { Perception of a structure in terms of aesthetics. Qualitative indi- } \\
\text { cator, assessed in } 10 \text {-points scale by experts: } 1 \text { = worst aesthet- } \\
\text { ical perception, } 10=\text { best aesthetical perception. }\end{array}$ & 0.06 \\
\hline$q_{6}$ & $\begin{array}{l}\text { Assembling } \\
\text { complexity }\end{array}$ & Min & points & $\begin{array}{l}\text { Complexity of assembling the structures in terms of required } \\
\text { machinery and work skills. Qualitative indicator, assessed in } \\
10 \text {-points scale by experts: } 1=\text { lowest assembling complexity, } \\
10=\text { highest assembling complexity. }\end{array}$ & 0.13 \\
\hline$q_{7}$ & $\begin{array}{l}\text { Simplicity of } \\
\text { foundation } \\
\text { design solution }\end{array}$ & Max & points & $\begin{array}{l}\text { Simplicity of foundation technical solution to bear the load of } \\
\text { over-ground timber structures. Qualitative indicator, assessed in } \\
10 \text {-points scale by experts: } 1=\text { most complex design solution, } \\
10=\text { most simple design solution. }\end{array}$ & 0.2 \\
\hline$q_{8}$ & $\begin{array}{l}\text { Simplicity of } \\
\text { structural sys- } \\
\text { tem production }\end{array}$ & Max & points & $\begin{array}{l}\text { Simplicity of structural system production determined by maxi- } \\
\text { mum number of uniform or identical elements needed for con- } \\
\text { struction, automation of processes and production time. Qualita- } \\
\text { tive indicator, assessed in } 10 \text {-points scale by experts: } 1=\text { most } \\
\text { complex production, } 10=\text { most simple production. }\end{array}$ & 0.2 \\
\hline
\end{tabular}

Note: *Max - higher value of criterion is preferred; Min - lower value of criterion is preferred.

\section{Multiple criteria assessment}

Following multiple criteria assessment framework by SAW method (Figure 1), decision-making matrix was developed (see Table 2).

Table 2. Decision-making matrix (source: developed by authors)

\begin{tabular}{|l|c|c|c|c|c|}
\hline & \multirow{2}{*}{ Max/Min } & \multirow{2}{*}{ Significance } & \multicolumn{3}{|c|}{ Alternatives } \\
\cline { 4 - 6 } & & & $A_{1}$ & $A_{2}$ & $A_{3}$ \\
\hline Achieved useful height of the building & Max & 0.08 & 4.3 & 3.72 & 4.4 \\
\hline Partial factor for material & Min & 0.13 & 1.25 & 1.2 & 1.12 \\
\hline Eco-friendliness of materials & Max & 0.10 & 10 & 9 & 6 \\
\hline Massiveness of structure & Min & 0.10 & 8 & 6 & 10 \\
\hline Structural aesthetics & Max & 0.06 & 10 & 9 & 8 \\
\hline Assembling complexity & Min & 0.13 & 7 & 8 & 10 \\
\hline Simplicity of foundation design solution & Max & 0.20 & 6 & 8 & 10 \\
\hline Simplicity of structural system production & Max & 0.20 & 10 & 5 & 7 \\
\hline
\end{tabular}


Calculations were performed by using MS Excel software. Normalisation of the matrix was performed according to Eq. (3) (Table 3) and weighed matrix according to Eq. (4) was calculated (Table 3). Finally, the efficiency of each structural system alternative was determined according to Eq. (5) (Table 4). Calculations allowed ranking of the alternative timber-based structural systems: $A_{1} \succ A_{3} \succ A_{2}$. According to calculation results, in this case, it is recommended to select a structural system designed from double tapered glued laminated beams and columns for construction of the shopping centre. The system compared to the other systems has several advantages - simpler to produce and assemble, more environmentally friendly and has the best aesthetical appearance.

Table 3. Normalised decision-making matrix (source: calculated by authors)

\begin{tabular}{|l|c|c|c|c|c|}
\hline & \multirow{2}{*}{ Max/Min } & \multirow{2}{*}{ Significance } & \multicolumn{3}{|c|}{ Alternatives } \\
\cline { 4 - 6 } & & & $A_{1}$ & $A_{2}$ & $A_{3}$ \\
\hline Achieved useful height of the building & Max & 0.08 & 0.9773 & 0.8455 & 1.0000 \\
\hline Partial factor for material & Min & 0.13 & 0.8960 & 0.9333 & 1.0000 \\
\hline Eco-friendliness of materials & Max & 0.10 & 1.0000 & 0.9000 & 0.6000 \\
\hline Massiveness of structure & Min & 0.10 & 0.7500 & 1.0000 & 0.6000 \\
\hline Structural aesthetics & Max & 0.06 & 1.0000 & 0.9000 & 0.8000 \\
\hline Assembling complexity & Min & 0.13 & 1.0000 & 0.8750 & 0.7000 \\
\hline Simplicity of foundation design solution & Max & 0.20 & 0.6000 & 0.8000 & 1.0000 \\
\hline Simplicity of structural system production & Max & 0.20 & 1.0000 & 0.5000 & 0.7000 \\
\hline
\end{tabular}

Table 4. Weighted decision-making matrix and final calculation results (source: calculated by authors)

\begin{tabular}{|c|c|c|c|c|}
\hline & \multirow{2}{*}{ Max/Min } & \multicolumn{3}{|c|}{ Alternatives } \\
\hline & & $A_{1}$ & $A_{2}$ & $A_{3}$ \\
\hline Achieved useful height of the building & Max & 0.0782 & 0.0676 & 0.0800 \\
\hline Partial factor for material & Min & 0.1165 & 0.1213 & 0.1300 \\
\hline Eco-friendliness of materials & Max & 0.1000 & 0.0900 & 0.0600 \\
\hline Massiveness of structure & Min & 0.0750 & 0.1000 & 0.0600 \\
\hline Structural aesthetics & Max & 0.0600 & 0.0540 & 0.0480 \\
\hline Assembling complexity & Min & 0.1300 & 0.1138 & 0.0910 \\
\hline Simplicity of foundation design solution & Max & 0.1200 & 0.1600 & 0.2000 \\
\hline Simplicity of structural system production & $\operatorname{Max}$ & 0.2000 & 0.1000 & 0.1400 \\
\hline \multicolumn{2}{|l|}{ Efficiency $\left(K_{j}\right)$} & 0.8797 & 0.8067 & 0.8090 \\
\hline \multicolumn{2}{|l|}{ Rank } & 1 & 3 & 2 \\
\hline
\end{tabular}

\section{Conclusions}

Due to substantial environmental benefits - absorption of $\mathrm{CO}_{2}$, lower processing and transportation energy and costs, good insulation properties, less global warming emissions compared to steel and concrete, timber structures are the most efficient alternative for construction of public buildings.

Selection of rational structural system is a multi-faceted problem which can be solved using MCDM techniques. Proposed multiple criteria assessment framework, based on SAW method, is easy to apply, therefore can be successfully used in practice, when it is necessary to select the most efficient structural system according to many conflicting quantitative and qualitative criteria.

The case study demonstrated an application of the proposed framework for selection of structural systems for a shopping centre in Lithuania. Three structural systems (1) double tapered glued laminated beams and columns, (2) LVL trusses and columns and (3) single tapered glued laminated beam and I type steel column were proposed and compared according to eight quantitative and qualitative criteria. Multiple criteria assessment revealed that the most efficient structural system shall be designed from double tapered glued laminated beams and columns.

The study, however, has some limitations. A system of criteria has to extend for more accurate results with additional multiple criteria assessment. These limitations will be solved in future research. 
Tupenaite, L.; Gecys, T.; Kanapeckiene, L.; Masoud Sajjadian, S.; Naimaviciene, J. 2019.

Selection of structural system for wooden public building: Multiple criteria approach

\section{Acknowledgements}

The present research has been partly financed under the EU ERASMUS+ projects "Sustainable High-Rise Buildings Designed and Constructed in Timber" (HiTimber) (Project No: 2017-1-DK-01-KA203-034242), "Sustainable Public Buildings Designed and Constructed in Wood“ (Pub-Wood) (Project No: 2018-1-LT01-KA203-046963), and "Knowledge Alliance for Sustainable Mid-Rise and Tall Wooden Buildings" (KnoWood) (Project No: 600903-EPP-1-2018-1-DK-EPPKA2-KA).

\section{References}

Archi Expo. (2019). Retrieved from http://www.archiexpo.es/

Balali, V., Mottaghi, A., Shoghli, O., \& Golabchi, M. (2014). Selection of appropriate material, construction technique, and structural system of bridges by use of multicriteria decision-making method. Transportation Research Record: Journal of the Transportation Research Board, 2431(1), 79-87. https://doi.org/10.3141/2431-11

Balali, V., Zahraie, B., Hosseini, A., \& Roozbahani, A. (2010). Selecting appropriate structural system: Application of PROMETHEE decision making method. In 2010 Second International Conference on Engineering System Management and Applications. Sharjah, United Arab Emirates.

Bitarafan, M., Hashemkhani Zolfani, S., Arefi, S. L., \& Zavadskas, E. K. (2012). Evaluating the construction methods of cold-formed steel structures in reconstructing the areas damaged in natural crises, using the methods AHP and COPRAS-G. Archives of Civil and Mechanical Engineering, 12(3), 360-367. https://doi.org/10.1016/j.acme.2012.06.015

Chatterjee, P., Athawale, V. M., \& Chakraborty, S. (2011). Materials selection using complex proportional assessment and evaluation of mixed data methods. Materials \& Design, 32(2), 851-860. https://doi.org/10.1016/j.matdes.2010.07.010

European Committee for Standardization (CEN). (2004). Timber structures - Structural Veneer Lumber - Requirements (EN 14374:2004). Brussels.

European Committee for Standardization (CEN). (2013). Timber structures - Glued Laminated Timber and Glued Solid Timber Requirements (EN 14080:2013). Brussels.

Frenette, C. D., Derome, D., Beauregard, R., \& Salenikovich, A. (2008) Identification of multiple criteria for the evaluation of light-frame wood wall assemblies. Journal of Building Performance Simulation, 1(4), 221-236. https://doi.org/10.1080/19401490802527661

Haghnazar Kouchaksaraei, R., Hashemkhani Zolfani, S., \& Golabchi, M. (2015). Glasshouse locating based on SWARA-COPRAS approach. International Journal of Strategic Property Management, 19(2), 111-122. https://doi.org/10.3846/1648715X.2015.1004565

Harte, A. M. (2009). Introduction to timber as an engineering material. In ICE Manual of Construction Materials. Institution of Civil Engineers.

Hildebrandt, J., Hagemann, N., \& Thrän, D. (2017). The contribution of wood-based construction materials for leveraging a low carbon building sector in Europe. Sustainable Cities and Society, 34, 405-418. https://doi.org/10.1016/j.scs.2017.06.013

Lill, I., Kanapeckiene, L., Tupenaite, L., \& Naimaviciene, J. (2017). Selection of the insulation materials for refurbishment purposes. Engineering Structures and Technologies, 9(2), 104-115. https://doi.org/10.3846/2029882X.2017.1339296

MacCrimmon, K. R. (1968). Decision making among multiple - attribute alternatives: A survey and consolidated approach. RAND Memorandum, RM-4823-ARPA.

Malesza, J., Miedzialowski, C., \& Ustinovichius, L. (2019). Analytical model tracing deformations in multistorey large timber panel building. Journal of Civil Engineering and Management, 25(1), 19-26. https://doi.org/10.3846/jcem.2019.7738

Podvezko, V. (2011). The comparative analysis of MCDA methods SAW and COPRAS. Inzinerine Ekonomika-Engineering Economics, 22(2), 134-146. https://doi.org/10.5755/j01.ee.22.2.310

Pollmeier. (2019). Retrieved from https://www.pollmeier.com/

Ramage, M. H., Burridge, H., Busse-Wicher, M., Fereday, G., Reynolds, T., Shah, D. U., ..., \& Scherman, O. (2017). The wood from the trees: The use of timber in construction. Renewable and Sustainable Energy Reviews, 68(Part 1), 333-359. https://doi.org/10.1016/j.rser.2016.09.107

Šaparauskas, J., Zavadskas, E. K., \& Turskis, Z. (2010). Evaluation of alternative building designes according to the three criteria of optimality. In The $10^{\text {th }}$ International Conference "Modern Building Materials, Structures and Techniques". Vilnius, Lithuania.

Šiožinyte, E., Antuchevičienè, J., \& Kutut, V. (2014). Upgrading the old vernacular building to contemporary norms: multiple criteria approach. Journal of Civil Engineering and Management, 20(2), 291-298 https://doi.org/10.3846/13923730.2014.904814

Tamošaitienè, J., \& Gaudutis, E. (2013). Complex assessment of structural systems used for high-rise buildings. Journal of Civil Engineering and Management, 19(2), 305-317. https://doi.org/10.3846/13923730.2013.772071

The Glued Laminated Timber Association (GLTA). (2019). Retrieved from http://www.glulam.co.uk/

Turskis, Z., Morkunaite, Z., \& Kutut, V. (2017). A hybrid multiple criteria evaluation method of ranking of cultural heritage structures for renovation projects. International Journal of Strategic Property Management, 21(3), 318-329. https://doi.org/10.3846/1648715X.2017.1325782

Turskis, Z., Urbonas, K., \& Daniūnas, A. (2019). A hybrid fuzzy group multi-criteria assessment of structural solutions of the symmetric frame alternatives. Symmetry, 11(2), 261. https://doi.org/10.3390/sym11020261

Zavadskas, E. K., Antucheviciene, J., Vilutiene, T., \& Adli, H. (2018). Sustainable decision-making in civil engineering, construction and building technology. Sustainability, 10(1), 14. https://doi.org/10.3390/su10010014 